\title{
Models of Portfolio-Based Teaching as a Early Childhood Social Emotional Skills Development Strategy
}

\author{
Anita Yus \\ Department of Early Childhood Education \\ Faculty of Education, State University of Medan \\ Medan, Indonesia \\ e-mail: anitayus.dikdas@gmail.com \\ Damaiwaty Ray \\ Department of Early Childhood Education \\ Faculty of Education, State University of Medan \\ Medan, Indonesia \\ Kamtini \\ Department of Early Childhood Education \\ Faculty of Education, State University of Medan \\ Medan, Indonesia
}

\begin{abstract}
This study aims to develop a portfolio-based teaching model as an early childhood social emotional development strategy. The specific objectives of the study are (1) to identify the achievement of social emotional development of children, (2) to design learning with portfolio-based teaching as a strategy to develop social emotional skills in early childhood education; and (3) to analyze effectiveness and the feasibility of a portfolio-based teaching model as an early childhood social emotional development strategy. Research development begins with needs analysis, formulation of model design, revisions based on advice and expert and teacher considerations. 89 samples of children and 12 kindergarten teachers were used in this study. Data were collected using observation method with checklist instrument, document analysis and continued focus group discussion. Data were analyzed using descriptive analysis. Descriptive analysis results show that $(1)$ it is known that the achievement of social emotional skills of childhood that tend to 'start developing' to 'grow as expected'; (2) portfolio-based teaching design with focus on components of child document preparation and assessment criteria; 3) the feasibility and effectiveness of the portfolio-based teaching model to enhance early childhood social emotional skills.
\end{abstract}

Keywords - Early childhood, portfolio-based teaching, and early childhood social emotional skills Development

\section{INTRODUCTION}

Education plays important role in the personal development of each individual. The quality of education could affect the quality on the individual learners, which includes early childhood education setting (Feeney, Christensen and Moravik, 2006). Childhood is an important period for individual development (Brewer (2007). Therefore, all parties need to understand the importance of childhood to optimizing individual growth and development.

Early childhood education (ECE) as a process helps children to develop all potentials of children including the development of emotional social skills. Currently, early childhood services are much needed by the community (Kemendikbud, 2015). The growth of ECE institutions is followed by various criticisms of the implementation of learning. Learning tends to be mechanistic and highly academic (Supriadi, 2004), children tend to wait and must follow teacher instruction (Gunawan, 2004); Learning activities are dominated by filling out worksheets and making children treat like robots.

In terms of teaching, it is necessary to know the learning model that is conducive to the development of the child, especially the development of social emotional aspects (Durlak, 2011). High social emotional skills in Kindergarten became an important factor of success at age 25 (Jones, Greenberg, \& Crowley, 2015). In terms of theory, it is necessary to examine the application of child development theory from experts to recognize the achievement of social emotional development of early childhood. Based on the above and taking into consideration the complex nature of learning as well as the new paradigm that sees the importance of learning to approach the linearity appraisal system used, it 
is necessary to examine the various learning models among which is how the teaching-based portfolio fosters children's social emotions. Portfolio-based teaching provides a great opportunity for children to move according to their needs (Machado, 2002) and through imaginative and creative children's activities that give them the opportunity to be comfortable with themselves, with others, with things and atmosphere awake.

\section{LITERATURE REVIEW}

\section{A. Social Emotional Development of Early Childhood}

Social-emotional developments include the experience, expression, and management of children's emotions and the ability to build positive and beneficial relationships with others (Cohen et al., 2005). Social-emotional development as the ability to form relationships with peers and adults around the child, experience organizing and expressing emotions socially and culturally, as well as exploring the environment and learning by all in the context of family, community and culture (Yates et al, 2008).

Experts agree that social-emotional developments relate to self, others and the environment. Social-emotional developments include experience, expression, emotional management of children and the ability to build positive and beneficial relationships with others (Cohen et al., 2005). The main social emotional skills identified for school success include: 1) associating with others, 2) following directions, 3) identifying and managing one's emotions and behaviors, 4) thinking of appropriate solutions to conflict, 5) enduring tasks, 6 ) engaging in social conversation and cooperative play, 7) correctly interpreting the behavior and emotions of others, and 8) feeling good about oneself and others (Dr. Smith in Carrie Shrier, 2014) and the social emotional ability of five-year-olds more focused on managing behavior, creating social relationships, and tolerating frustration with peers (Blair \& Diamond, 2008; Konold \& Pianta, 2005).

\section{B. Portfolio-Based Teaching}

Teaching is an attempt to help others develop all their potential through the interaction of all components manifested in the form of a series of activities (Moore, 2005; Dunkin \& Biddle, 1974; Joyce and Weil, 1996; and Slavin, 2004). In teaching, the portfolio is defined as a description of various work performance of children (Fusco, Quinn and Hauck, 1993; Machado, 2002).

Implementation of portfolio assessment in teaching with CORP model, ie 1) collection, 2) organizing, 3) reflection, and 4) presentation (Wyaatt III and Looper, 1999) combined with learning phase consisting of preparation, implementation and assessment (Moskal and Layden, 2006). In the preparation stage of the activity, 1) discuss the form of the portfolio document and how to do it, and 2) approve the assessed component. In the implementation phase, the following activities are carried out, 1) carrying out the agreed activities, 2) collecting the work, and 3) reflecting on the work and activities. In the assessment phase 1) show or display the results of the work produced, and 2) make a good judgment by teachers, peers and by students themselves.

\section{Portfolio-based Teaching and Social Emotional Development}

Portfolio-based teaching provides opportunities for cooperation between teachers and children and children in generating portfolios (Slavia dan Ysseldyke, 1995). The cooperation is realized in the form of consultation or discussion on the criteria of work to be produced, the process of completing the task, determining the work specified as portfolio and other materials. Portfolio-based teaching encourages active children to discuss, learn collaboration, communicate, and give appreciation to their own work and friends, and team players.

Learning activities in portfolio-based teaching produce work as evidence of children's ability to demand high attention to focus on work. The work produced by the child needs to be presented in front of other children. It takes courage of children at the time of presentation and other children need to appreciate the work of his friend even though the work is different from other works or own work.

The process of communication opens opportunities for children to perform learning activities, such as thinking, doing tasks or express opinions. The process of cooperation in portfolio-based teaching will encourage self-evaluations and replication thinking (Slavis and Ysseldyke, 1995). The process encourages the child to be persistent and patient, to have peer appreciating skills.

\section{RESEARCH METHODOLOGY}

This research was conducted on the kindergarten of North Sumatra. The population includes Medan, Binjai, Lubuk Pakam, Tebing Tinggi dan Pematang Siantar that have early childhood education institutions either kindergarten or other early childhood institution in which have educators or teachers. Thus the researchers used samples from several city/districts in Sumatera Utara.

The method used in this research is mixed method with explanatory technique. Sequential explanations are applied to collect and analyze quantitative data on the social emotional skill of the Kindergarten group of children (ages 4 - 5 years) in the first stage followed by the collection and analysis of qualitative data in the second stage. Subjects involved as many as 89 children and 12 teachers' kindergarten B in North Sumatra. This development study yields models evaluated according to the Richey and Nelson models performed repeatedly with formative assessment in accordance with the Van den Akker model to optimize the quality of product implementation in certain situations. By adopting these two models will produce a quality portfolio-based teaching model.

This research development is conducted in cycling activities based on the design and examining the learning activity which is followed by guided training in direct practice, discussion and consultation. The result of this 
research is a research product which is good in quality including methodology, theoretically and empirically.

\section{FINDINGS AND DISCUSSIONS OF RESEARCH}

\section{A. Development of Kindergarten Children B}

The achievement of social emotional skills by reviewing the major social emotional skills identified for school success as proposed Dr. Smith in the article Carrie Shrier (2014). The result of data analysis shows that the indicator of developmental aspect of social emotional skill of kindergarten children B that tend to appear in everyday behaviour is a number of twenty indicators. Behavioural indicators showing these social emotional skills are presented in Table 1.

Table I Percentage of Indicators Aspects of Social Emotional Skills of Kindergarten Children Based on Occurrences

(Adoption of Dr. Smith in Carrie Shrier, 2014)

\begin{tabular}{|c|c|c|}
\hline $\begin{array}{l}\text { Aspects of } \\
\text { Social } \\
\text { Emotional } \\
\text { Skills }\end{array}$ & $\begin{array}{l}\text { Social Emotional Skills } \\
\text { Indicator }\end{array}$ & $\begin{array}{l}\text { Persentag } \\
\text { e (\%) }\end{array}$ \\
\hline \multirow{3}{*}{$\begin{array}{l}\text { Getting along } \\
\text { with others } \\
\text { (parents, } \\
\text { teachers and } \\
\text { peers) }\end{array}$} & $\begin{array}{l}\text { 1) Conducting activities with } \\
\text { parents }\end{array}$ & 100 \\
\hline & $\begin{array}{l}\text { 2) Conducting activities with } \\
\text { teachers }\end{array}$ & 91.01 \\
\hline & $\begin{array}{l}\text { 3) Conducting activities with } \\
\text { peers }\end{array}$ & 76.40 \\
\hline \multirow[t]{2}{*}{$\begin{array}{l}\text { Following } \\
\text { directions }\end{array}$} & $\begin{array}{l}\text { 4) Do something according to } \\
\text { instructions given }\end{array}$ & 78.65 \\
\hline & $\begin{array}{l}\text { 5) Completed the task as } \\
\text { instructed }\end{array}$ & 61.80 \\
\hline \multirow{3}{*}{$\begin{array}{l}\text { Identifying } \\
\text { and regulating } \\
\text { one's } \\
\text { emotions and } \\
\text { behavior }\end{array}$} & $\begin{array}{l}\text { 6) Express yourself according } \\
\text { to the emotional condition } \\
\text { shown through the picture }\end{array}$ & 78.65 \\
\hline & $\begin{array}{l}\text { 7) Give examples of self- } \\
\text { expression in certain } \\
\text { emotional states (eg sad) }\end{array}$ & 68.54 \\
\hline & $\begin{array}{l}\text { 8) Invite to play a friend } \\
\text { who is sad }\end{array}$ & 38.20 \\
\hline \multirow{2}{*}{$\begin{array}{l}\text { Thinking of } \\
\text { appropriate } \\
\text { solutions to } \\
\text { conflict }\end{array}$} & $\begin{array}{l}\text { 9) Ask for help if you have } \\
\text { trouble }\end{array}$ & 78.65 \\
\hline & $\begin{array}{l}\text { 10) Determine the right way } \\
\text { if you have difficulty (eg } \\
\text { when thirsty to know to } \\
\text { drink and find a drink) }\end{array}$ & 57.30 \\
\hline \multirow[t]{2}{*}{$\begin{array}{l}\text { Persisting on } \\
\text { task }\end{array}$} & $\begin{array}{l}\text { 11) Working on the tasks } \\
\text { assigned to completion }\end{array}$ & 61.80 \\
\hline & 12) Collect assigned tasks & 69.66 \\
\hline \multirow{4}{*}{$\begin{array}{l}\text { Engaging in } \\
\text { social } \\
\text { conversation } \\
\text { and } \\
\text { cooperative } \\
\text { play }\end{array}$} & $\begin{array}{l}\text { 13) Talk to friends when they } \\
\text { are invited }\end{array}$ & 100.00 \\
\hline & $\begin{array}{l}\text { 14) Take initiative to invite } \\
\text { friends to talk }\end{array}$ & 39.33 \\
\hline & $\begin{array}{l}\text { 15) Take an active role in the } \\
\text { activities of playing } \\
\text { together }\end{array}$ & 65.17 \\
\hline & 16) Sharing a toy tool in a & 66.29 \\
\hline
\end{tabular}

\begin{tabular}{|c|c|c|}
\hline & game together & \\
\hline \multirow{2}{*}{$\begin{array}{l}\text { Correctly } \\
\text { interpreting } \\
\text { other's } \\
\text { behavior and } \\
\text { emotions }\end{array}$} & $\begin{array}{l}\text { 17) guess the feelings of } \\
\text { friends' emotions from } \\
\text { the behaviours seen }\end{array}$ & 50.56 \\
\hline & $\begin{array}{l}\text { 18) Responding to the } \\
\text { behavior that friends } \\
\text { show }\end{array}$ & 76.40 \\
\hline \multirow{2}{*}{$\begin{array}{l}\text { Feeling good } \\
\text { about oneself } \\
\text { and others }\end{array}$} & $\begin{array}{l}\text { 19) Shows a happy } \\
\text { expression during activity }\end{array}$ & 65.17 \\
\hline & $\begin{array}{l}\text { 20) Feel happy to be around } \\
\text { peers }\end{array}$ & 80.90 \\
\hline \multicolumn{2}{|c|}{$\begin{array}{l}\text { Rata-rata persentase frekuensi perilaku } \\
\text { keterampilan sosial }\end{array}$} & 70.22 \\
\hline
\end{tabular}

Table 1 show that the average child kindergarten $B$ in North Sumatra already has a social emotional skill indicator of $70.22 \%$. Means still amounted to $29.78 \%$ social emotional skill behaviour is not owned average child kindergarten B in North Sumatra. If this percentage of developmental achievement is associated with the principle of normal curves, i.e. $-1 \mathrm{Sd}$ to $+1 \mathrm{Sd}$ of $72 \%$ then the percentage of attainment of social emotional behaviour that emerges can be stated normal. There are indicators that are easy for children and there are indicators that require more time and practice for children.

The results of the analysis on each social emotional skill indicator shows that there is an social emotional skill behaviour that most of the kindergarten children have not yet had, that is' an indicator to invite friends who are more sadly owned as much as $38.20 \%$ of kindergarten children B and take initiative to invite peers owned by $39.33 \%$ of kindergarten children B. Moderate social emotional behaviour indicator 'states the emotional condition of friends from the behaviour seen' owned as much as $50.56 \%$ kindergarten children B. This result is described the theory of social emotional development, i.e. children aged 4-6 years is in the development of sensitivity of individuality (Erik Erikson's Social Theory). The child is still in the experimental phase, trial and error learning and perfecting social emotional skills (Kostelnik, et al., 2006). At this time the child is learning to be self-sufficient in ways such as self-organization, toilets, eating, and dressing and learning to maintain the attachment that keeps the child safe from the age of three, as well as distinguishing oneself as individuals (Feeney, et al., 2006). This condition tends to make the child like not want to be friends or invite friends to be together. Parents with disadvantaged economies lack the time to provide facilities or with their children in developing positive things on the child's social emotional skills (Bernier A, Carlson SM, Whipple N, 2010). The behavior of parents with socioeconomic status is less fortunate as the developer of social emotional skills, less responsive to the child's behaviour and less facilitate the child in the development of social emotional skills (Evan GW, 2004).

The results of data analysis of social emotional skills achievement shows that the behaviour that describes the achievement of social emotional skill of Kindergarten Children is in the range tends to 'start developing' until 'grow to grow as expected', that is $34,83 \%$ Kindergarten B children are on the achievement start expanded and $61.80 \%$ were in progress as expected. There are several factors that influence 
the development of social emotional skills. Cultural factors affect children's growing understanding of the emotional outcomes, and their learning about which emotions are appropriate to display in which situations (Thompson and Goodvin, 2005). Cultures vary in terms of what one is expected to feel, and when, where, and how one may express different feelings "(Cheah and Rubin, 2003). The results of data analysis of the achievement of social emotional skill of the kindergarten children of B Sumatera Utara are presented in Table 2.

Table 2 Frequency Distribution of Social Emotional Skills Achievements Before After Portfolio-based Teaching

\begin{tabular}{|c|c|c|c|c|}
\hline \multirow{2}{*}{ Achievements } & \multicolumn{2}{|c|}{ Absolute frequency } & \multicolumn{2}{c|}{ Relative Frequency } \\
\cline { 2 - 5 } & Before & After & Before & After \\
\hline BSH & 48 & 55 & 53,93 & 61,80 \\
\hline MB & 28 & 31 & 31,46 & 34,83 \\
\hline BB & 13 & 3 & 14,61 & 3,37 \\
\hline Total & 89 & 89 & 100 & 100 \\
\hline
\end{tabular}

Note: $\mathrm{BSH}=$ develops as expected, $\mathrm{MB}=$ starts to grow, and $\mathrm{BB}=$ undeveloped

Skills indicators that many Kindergarten children B do not have are an indicator of 'initiative to invite friends who are sad to play' and 'take the initiative to invite peers to talk'. These two indicators are among a number of behaviours that children have difficulty in dealing with peers or others (Kristin, accessed September 9, 2017).

Differences in achievement of social emotional skills development may occur due to various factors. The most frequently studied factors are family factors, such as how the family responds to the child's daily behaviour in developing social emotional skills. In addition, biological factors are also widely studied by experts as factors affecting social emotional development.

Table 2 shows that there is an increase in the achievement of emotional social development by $5.24 \%$ after the children do learning activities in portfolio-based teaching. Table 2 also shows that the achievement of the social emotional skills of kindergarten children tends to 'start developing' towards 'grow as expected'. This achievement can be seen from the behaviour of children who are able and willing to show the results of work produced and have confidence even though the work on display is different from the work of his friend.

\section{B. Portfoli-Based Teaching Model}

Portfolio-based teaching is developed based on the CORP model portfolio assessment model, i.e. 1) collecting, 2) organizing, 3) reflection, and 4) presenting (Wyaatt III and Looper, 1999) combined with a learning stage consisting of preparation, implementation and assessment (Moskal and Layden, 2006). Results of data analysis obtained through observation and focus group discussion obtained activity of teachers and children that can be done in learning. The results of data analysis indicate that the stages arranged can be applied in learning in kindergarten. At the time of practicing the learning stages of the portfolio-based teaching model obtained various activities of teachers and children that can be done at each stage of learning (see Table 3). Activities undertaken by the child during the learning that produced the document. The document is used as evidence of the child's success in learning activities.

Table 3 Teacher and Child Activities in Portfolio Based Teaching

\begin{tabular}{|c|c|c|c|}
\hline \multirow[t]{2}{*}{ Stage } & \multirow{2}{*}{$\begin{array}{c}\text { Teaching } \\
\text { Activity }\end{array}$} & \multicolumn{2}{|c|}{ Activity } \\
\hline & & Teacher & Children \\
\hline \multirow[t]{2}{*}{ Preparation } & $\begin{array}{l}\text { Discuss } \\
\text { activities } \\
\text { performed } \\
\text { for } \\
\text { generated } \\
\text { portfolio } \\
\text { document } \\
\text { form }\end{array}$ & 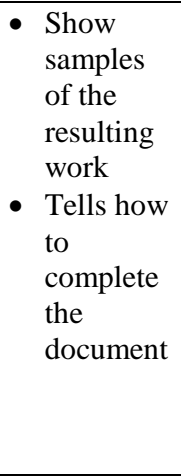 & $\begin{array}{l}\text { - Observin } \\
\mathrm{g} \\
\text { example } \\
\text { s of } \\
\text { given } \\
\text { works } \\
\text { - Do } \\
\text { somethin } \\
\text { g to } \\
\text { produce } \\
\text { the work } \\
\text { to be } \\
\text { collected }\end{array}$ \\
\hline & $\begin{array}{l}\text { Agree on } \\
\text { the } \\
\text { assessed } \\
\text { componen } \\
\mathrm{t}\end{array}$ & $\begin{array}{l}\text { Inform the } \\
\text { requirements } \\
\text { to consider } \\
\text { in producing } \\
\text { the work }\end{array}$ & $\begin{array}{l}\text { Accept } \\
\text { the } \\
\text { informed } \\
\text { terms }\end{array}$ \\
\hline \multirow[t]{3}{*}{$\begin{array}{l}\text { Implementati } \\
\text { on }\end{array}$} & $\begin{array}{l}\text { Carry out } \\
\text { the agreed } \\
\text { learning } \\
\text { activities }\end{array}$ & $\begin{array}{l}\text { Motivating } \\
\text { children to } \\
\text { make the } \\
\text { most of their } \\
\text { activities. }\end{array}$ & $\begin{array}{l}\text { Conductin } \\
\text { g learning } \\
\text { activities } \\
\text { and } \\
\text { producing } \\
\text { one work } \\
\text { as an } \\
\text { artefact } \\
\text { and as } \\
\text { evidence } \\
\text { of } \\
\text { learning }\end{array}$ \\
\hline & $\begin{array}{l}\text { Collect } \\
\text { the } \\
\text { resulting } \\
\text { work }\end{array}$ & $\begin{array}{l}\text { Encourage } \\
\text { the child to } \\
\text { complete all } \\
\text { works within } \\
\text { the agreed } \\
\text { time limit }\end{array}$ & $\begin{array}{l}\text { Shows the } \\
\text { completed } \\
\text { work to } \\
\text { the } \\
\text { teacher }\end{array}$ \\
\hline & $\begin{array}{l}\text { reflecting } \\
\text { on works } \\
\text { and } \\
\text { activities }\end{array}$ & $\begin{array}{l}\text { Ask the child } \\
\text { to express } \\
\text { his feelings } \\
\text { during his } \\
\text { activities and } \\
\text { in his own } \\
\text { work and the } \\
\text { work of his } \\
\text { friend }\end{array}$ & $\begin{array}{l}\text { Express } \\
\text { the } \\
\text { feelings } \\
\text { that arise } \\
\text { during the } \\
\text { work of } \\
\text { the work } \\
\text { and of his } \\
\text { own work } \\
\text { and the } \\
\text { work of } \\
\text { his friend }\end{array}$ \\
\hline Assessment & $\begin{array}{l}\text { displaying } \\
\text { the } \\
\text { resulting }\end{array}$ & $\begin{array}{l}\text { Arrange the } \\
\text { child's work } \\
\text { on the }\end{array}$ & $\begin{array}{l}\text { Together } \\
\text { with the } \\
\text { teacher }\end{array}$ \\
\hline
\end{tabular}




\begin{tabular}{|l|l|l|l|}
\hline & work & $\begin{array}{l}\text { display } \\
\text { boards }\end{array}$ & $\begin{array}{l}\text { arranges } \\
\text { the child's } \\
\text { work on } \\
\text { the } \\
\text { display } \\
\text { boards }\end{array}$ \\
\cline { 2 - 4 } & $\begin{array}{l}\text { Presentati } \\
\text { on of the } \\
\text { work }\end{array}$ & $\begin{array}{l}\text { Ask the child } \\
\text { to present } \\
\text { the work } \\
\text { Giving } \\
\text { appreciation } \\
\text { to children's } \\
\text { work } \\
\text { Encourage } \\
\text { parents, } \\
\text { children and } \\
\text { parents to } \\
\text { assess } \\
\text { children's } \\
\text { work }\end{array}$ & $\begin{array}{l}\text { ng the } \\
\text { work } \\
\text { Giving } \\
\text { appreci } \\
\text { ation to } \\
\text { the } \\
\text { work of } \\
\text { his } \\
\text { friend }\end{array}$ \\
& $\begin{array}{l}\text { Put the } \\
\text { child's work } \\
\text { into the } \\
\text { folder }\end{array}$ & $\begin{array}{l}\text { Help } \\
\text { teachers } \\
\text { put works } \\
\text { into } \\
\end{array}$ \\
& & folders \\
\hline
\end{tabular}

The results of the analysis on teacher activity indicate that the whole teacher has done portfolio-based teaching with various forms of activity and quality. Furthermore, the results of the analysis indicate that teacher activity in learning of portfolio-based teaching model is at interval 2 to 3 . That is, teacher activity in 'start to do' learning until 'done with simple' portfolio based teaching activity. Some activities that have not been done due to the difficulty of teachers find activities that match the characteristics and development of children, namely children aged 5-6 years. As many as 50\% of teachers have not given the opportunity for children to choose their own documents (artefacts) to be done. Other learning activities that have not been done by as many as $48 \%$ of teachers in learning portfolio-based teaching model is to document the artefacts into the folder of each child. The teacher collects all the work of the child in one place and at another time the teacher will insert the document into the folder of each child without involving the child. This activity is related to the presentation of children's work by the children themselves and display the work of children who have not been maximized by the teacher.

\section{The Effectiveness and Feasibility Model Used in Kindergarten $B$}

The results of data analysis show that effective portfoliobased teaching model is used to develop emotional social skill of early childhood. Portfolio-based teaching is conducted systematically so that children can follow the learning stages that produce artefacts as evidence of child learning (Hilary Seitz \& Carol Bartholomew, 2008). The role of teachers in learning provides opportunities for children to develop themselves (Anita, 2017). In fact, portfolio-based teaching effectively develops children based on multiple intelligences theory studies (Stefakanis, 2002). The effectiveness is seen from the improvement of children's emotional social skill development an average of $5.24 \%$. This is obtained by the child after the child performs the learning activities in portfolio-based teaching. Other than that, experiences with family members and teachers provide an opportunity for young children to learn about social relationships and emotions through exploration and predictable interactions (Shonkoff 2004). In other words, those children who are systematically taught social and emotional skills like how to manage their distressing emotions better, empathize and collaborate do better; have fewer problems (Goleman, 2008). Based on the explanation it can be argued that the role of teachers in portfolio-based teaching is to facilitate, to review, to collaborate, to assess, to learn and to be resource (Hilary Seitz \& Carol Bartholomew, 2008).

\section{CONCLUSION}

Based on the results of analysis and discussion of research results that have been raised can be concluded that there are eight activities that teachers need to do in portfolio-based teaching to develop the emotional social skills of kindergarten children.

The quality of implementation of portfolio-based teaching conducted by teachers in kindergarten B is in the two-to-three category, namely the teacher has started to do until done simply.

Learning activities that need to be improved by the teacher is to give opportunity to children to choose activity of children learning that relate significantly to the development of emotional social skill of child.

Portfolio-based teaching is effectively used by teachers as an emotional social skill development strategy for Kindergarten children especially in choosing activities that children will perform and presenting the work produced by the child.

\section{REFERENCES}

[1] Anita Yus, How Teachers Comprehend and Support Children's Needs to be Scientists, Advances in Social Science, Education and Humanities Research (ASSEHR), volume 58, 3rd International Conference on Early Childhood Education (ICECE-16) 62-68. Copyright (C) 2017, the Authors. Published by Atlantis Press. This is an open access article under the CC BY-NC license (http://creativecommons.org/licenses/bync/4.0/

[2] Arter, Judith, A. dkk., Portfolios for Assessment and instruction, 2003. (http://www.oxford.anglican..org/portfolio/whatis.shtml)

[3] Bernier A, Carlson SM, Whipple N. From External regulation to self regulation: Early Parenting Precursors of Young Children's Executive Functioning. Child Development. 2008:81(1):326---339

[4] Blair, C., A. Diamon, Biological processes in prevention and intervention: The promotion of self-regulation as a means of preventing school failure, Developmental Psychopathology, 20 (3).2008. 899-911

[5] Brewer, Jo, Ann. Introduction to Early Childhood Education Preschool Through Primary Grades sixth edition. New York: Pearson Education, Inc, 2007

[6] Carrie Shrier, Kindergarten readiness: Social and emotional development, Michigan State University Extension, 2014.

[7] Cheah, C., and K. Rubin. "European American and Mainland Chinese Mothers' Socialization Beliefs Regarding Preschoolers' Social Skills,' Parenting: Science and Practice, 2003.Vol. 3, No. 1, 1-21 
[8] Cohen, J., and others. Helping Young Children Succeed: Strategis to Promote Early Childhood Social and Emotional Development, Washington, DC: National Conference of State Legislatures and Zero to Three. 2005.

[9] Dunkin, Michael J\& Biddle, Bruce J. The Study of teaching.USA:Holt, Rinehart and Winston,Inc, 1974.

[10] Durlak, J. A., Weissberg, R. P., Dymnicki, A. B., Taylor, R. D., \& Schellinger, K. B. The impact of enhancing students' social and emotional learning: A meta-analysis of school-based universal interventions. Child Development, 2011.821, 405-432

[11] Evans GW, The environment of childhood poverty, American Psychologist 02 2004;59(2):77---92

[12] Feeney, Stephanie, Doris Christensen, and Eva, Moravik,. Who am I in the lives of children seventh edition. Columbus, Ohio:Pearson Merril Prentice Hall, 2006.

[13] Fusco, Esther, Mary C., Quinn, dan Marjorie Hauck, The Portfolio Assessment A Practical Guide for Implementing ang Organizing Portfolio Evaluation, New York: Berrent Publications Inc., 1993

[14] Goleman, Daniel. Emotional Intelligent (Kecerdasan emosional), Jakarta: PT Gramedia Pustaka Utama., 2008

[15] Gunawan, Adi, W. Genius learning strategy practical guidance for applying accelerated learning ( petunjuk praktis untuk menerapkan accelerated learning). Jakarta: Penerbit PT Gramedia Pustaka Utama, 2004.

[16] Hilary Seitz \& Carol Bartholomew, Powerful Portfolios for Young Children, Early Childhood Educ Journal., Published online: 29 March 2008

[17] Jennings, P. A., \& Greenberg, M. T. The prosocial classroom: Teacher social and emotional competence in relation to student and classroom outcomes. Review of Educational Research, 2009. 79, 491-525.

[18] Jones,D.E., Greenberg, M., \& Cowley, M. Early social-emotional functioning and public health: the relationship between kindergarten social competence and future wellness. American Journal of Public Health, 2015.105, 2283-2290.

[19] Joyce, Bruce. Dan Marsh, Weil. Models of Teaching Fifth Edition. Boston: Allyn and Bacon, 1996

[20] Konold,T.R.,dan Pianta,R.C., Empirically-derived, person-oriented patterns of school readiness in typically-developing children:
Description and prediction to first-grade achievement. Applied Developmental Science, 9 (4) (2005), pp. 174-187

[21] Kostelnik, M.J., Whiren, A.P., Soderman, A.K, \& Gregory, K., Guiding children's social development theory to practice. $\left(5^{\text {th }}.\right)$. Clifton Park, NY: Thomson Delmar Learning, 2006.

[22] Kristin Stanberry, Understanding Social and Emotional Development in Preschoolers, National Center for Learning Disabilities, Inc. All Rights Reserved, diakses 9 September, 2017.

[23] Machado, Franssisco. Portfolio Based Learning (PBL). 2002. (http://www.wsu.edu/provost/teaching.htm)

[24] Moore, Kenneth, D. Effective Instructonal Strategies from Theory to Practice. London: Sage Publication Ltd. 2005.

[25] Roopnarine, Jaipaul L dan James E Johnson,. Approach to early childhood education fourth edition, Colombus, Ohio: Pearson Merril Prentice Hall, 2005.

[26] Shonkoff, J. P. Science, Policy and the Developing Child: Closing the Gap Between What We Know and What We Do. Washington, DC: Ounce of Prevention Fund, 2004.

[27] Slavia, John, and James, E. Ysseldyke, Assessment sixth edition. Boston: Hougton Mifflin Company, 1995

[28] Stefakanis, Evangeline, Harris., Multiple Inteligences and Portofolios A Window into the Learner's Mind. NH: Portsmouth: Heinemann, 2002

[29] Slavin, Robert. E., A Model of Effective Instruction, 2004. (http://www.edu.provost/teaching.htm)

[30] Snelbecker, Glenn, E. Learning theory, instructional theory and psychoeducational design.New York: McGraw-Hill Book Co, 1974.

[31] Supriadi, Dedi, Membangun Bangsa Melalui Pendidikan, Editor Rohmat Mulyana. Bandung: PT Remaja Rosdakarya, 2004.

[32] Thompson, R. A. The Development of the Person: Social Understanding, Relationships, Self, Conscience, in Handbook of Child Psychology (Sixth edition), Volume 3: Social, Emotional, and Personality Development. Edited by N. Eisenberg. Hoboken, NJ: Wiley and Sons, 2006.

[33] Wyaatt III, Robert, L., and Sandar Looper, So You Have to Have A Portfolio, A Teacher's Guide ti Preparation and Presentation. California: Corwin Press Inc. 1999 